\title{
Rational use of rubella vaccine for prevention of congenital rubella syndrome in the Americas
}

\author{
Alan R. Hinman, ${ }^{1}$ Bradley S. Hersh, ${ }^{2}$ and Ciro A. de Quadros ${ }^{2}$
}

\begin{abstract}
Rubella is a viral disease with minor morbidity and few complications unless it is contracted by a pregnant woman. Rubella infection during the first trimester of pregnancy often leads to fetal death or severe congenital defects (congenital rubella syndrome, CRS). Rubella remains endemic in many countries of Latin America and the Caribbean. It has been estimated that 20000 or more infants are perhaps born with CRS each year in Latin American and Caribbean countries. While the inclusion of rubella vaccination into routine childhood immunization will decrease rubella virus circulation among young children, it will not have immediate impact on the transmission of rubella among adults or the occurrence of CRS. A one-time mass campaign targeting both males and females 5 to 39 years of age with measles-mumps-rubella or measlesrubella vaccine followed by the use of measles-mumps-rubella vaccine in routine early childhood vaccination will prevent and control both rubella and CRS promptly. In April 1988, the Ministers of Health of the English-speaking Caribbean targeted rubella for elimination by the end of the year 2000 using the vaccination strategy outlined above. The rubella elimination experience of these countries will provide useful information for the eventual elimination of rubella virus from the Americas.
\end{abstract}

Rubella is typically a mild exanthematous disease with minor morbidity and few complications unless it is contracted by a pregnant woman (particularly during the first trimester). In such cases, rubella often leads to fetal death or severe congenital defects including blindness, deafness, cardiovascular anomalies, and mental retardation [congenital rubella syndrome (CRS)]. During the last major epidemic of rubella in the United States in 1964-1965,

\footnotetext{
The Task Force for Child Survival and Development, Atlanta, Georgia, USA. Mailing address: 750 Commerce Drive, Suite 400, Decatur, GA 30030. Tel.: 404-687-5636; fax: 404-371-0415; E-mail: ahinman@taskforce.org

2 Pan American Health Organization, Special Program for Vaccines and Immunization, Washington, DC, USA.
}

there were an estimated 11000 fetal deaths or induced terminations of pregnancy, and 20000 infants were born with CRS (1).

Rubella vaccines were introduced in 1969 and since that time have been widely used in many industrialized countries. Because the vaccines contain attenuated live rubella viruses, there was initial concern that vaccination of women later found to be pregnant might result in fetal infection and deformity. Extensive study of this topic, including follow-up of more than 500 susceptible women in the United States who received rubella vaccine within the 3 months before or after conception, indicated that fetal infection occasionally may occur, but there were no instances of congenital defects associated with CRS (2). The currently recommended approach to vaccinating women of childbearing age is to ask them if they think they are pregnant or may become pregnant in the next 3 months. If the answer is "yes," they should not receive the vaccine; if the answer is "no," they should be vaccinated (2). If a woman becomes pregnant within 3 months after vaccination, she should be counseled about the theoretical concern for the fetus, but rubella vaccination should not ordinarily be a reason to consider interruption of pregnancy. Vaccineinduced immunity is long-lasting, probably lifelong. Few side effects are associated with the rubella vaccine; the most significant is transient arthralgia or arthritis, which may occur 
in $25 \%$ of susceptible women who are vaccinated. This is rare in both children and males. There is conflicting evidence as to whether long-term arthritis may occasionally occur.

\section{BURDEN OF RUBELLA AND CONGENITAL RUBELLA SYNDROME IN THE AMERICAS}

Other than for the United States and Canada, limited data are available on the ongoing burden of rubella and CRS in the Americas (3). However, cases of CRS or documented fetal infection have been documented in Barbados (4), Belize (4), Brazil $(5,6)$, Cuba (7), Jamaica $(8,9)$, Mexico (10), Panama (11), and Trinidad (12). It has been estimated that, in the absence of major epidemics, more than 20000 infants are born with CRS each year in the Americas (13).

There is more information about susceptibility to rubella (14-30). Serological surveys in at least 13 countries of the Americas have documented a wide range of susceptibility in women of childbearing age and in young adults of both sexes (Table 1). Persons living on islands or in rural areas are more likely to be susceptible than people in urban areas; up to one-half of adults of childbearing age in these settings are susceptible. Consequently, it is clear that, in addition to the ongoing endemic incidence, the potential exists in many countries for major epidemics of rubella to occur (with consequent CRS). In the absence of effective immunization programs, there is at least some risk of CRS in all countries. Countries without direct evidence of the magnitude of risk may want to consider serological studies such as surveys of pregnant women or of women at delivery.

\section{CURRENT USE OF RUBELLA VACCINE IN THE AMERICAS}

\section{Vaccine strategies}

The United States and Canada were the first countries in the Region to use

TABLE 1. Percent of persons with antibodies to rubella in countries of the Americas, 1962-1991

\begin{tabular}{|c|c|c|c|c|c|}
\hline Country & Setting & Year & $\begin{array}{l}\text { Targeted ages } \\
\text { (years) }\end{array}$ & $\%$ positive & Ref. \\
\hline \multirow[t]{3}{*}{ Argentina } & Buenos Aires & 1967 & $17-35$ & $79-83$ & (14) \\
\hline & Buenos Aires & 1968 & $15-34$ & $79-86$ & (15) \\
\hline & Rural & 1968 & $15-34$ & $73-92$ & (15) \\
\hline Barbados & Bridgetown & 1972 & $21-25$ & 60 & (16) \\
\hline \multirow[t]{4}{*}{ Brazil } & São Paulo & 1968 & 15-34 & $83-91$ & (15) \\
\hline & Rural & 1968 & $15-34$ & $88-90$ & (15) \\
\hline & São Paulo & 1968 & Pregnant women & 87 & (17) \\
\hline & & 1991 & $15-39$ & 93 & (18) \\
\hline \multirow[t]{2}{*}{ Chile } & Santiago & 1968 & $15-34$ & $89-98$ & (15) \\
\hline & Rural & 1968 & $15-34$ & 100 & (15) \\
\hline \multirow[t]{5}{*}{ Costa Rica } & & 1971 & $15-39$ & 70 & (19) \\
\hline & & 1973 & $17-40$ & 71 & (20) \\
\hline & & 1980 & $15-44$ & 77 & (21) \\
\hline & Urban & 1984-1985 & $25-44$ & $87-93$ & (22) \\
\hline & Rural & 1984-1985 & $25-44$ & $84-87$ & (22) \\
\hline \multirow[t]{3}{*}{ Jamaica } & Kingston & 1967 & $17-29$ & $52-67$ & (14) \\
\hline & Kingston & 1968 & $15-34$ & $52-65$ & (15) \\
\hline & Rural & 1968 & $15-34$ & $42-52$ & (15) \\
\hline \multirow[t]{3}{*}{ Mexico } & Urban & 1969 & $15-39$ & $93-98$ & (23) \\
\hline & Urban & $1987-1988$ & $10-14$ & 74 & (24) \\
\hline & Rural & 1987-1988 & $10-14$ & 63 & (24) \\
\hline \multirow[t]{4}{*}{ Panama } & Panama City & 1968 & 15-34 & $61-66$ & (15) \\
\hline & Rural & 1968 & 15-34 & $30-42$ & (15) \\
\hline & Rural & 1976-1977 & $15-30$ & 29 & (25) \\
\hline & Urban & 1976-1977 & $15-30$ & 73 & (25) \\
\hline \multirow[t]{2}{*}{ Peru } & Lima & 1968 & $15-34$ & $67-89$ & (15) \\
\hline & Rural & 1968 & $15-34$ & $39-78$ & (15) \\
\hline Suriname & Paramaribo & $1970-1971$ & Pregnant women & 55 & (26) \\
\hline \multirow[t]{4}{*}{ Trinidad } & South Trinidad & 1966 & $15-29$ & 25 & (27) \\
\hline & Port of Spain & 1967 & $17-29$ & $47-54$ & (14) \\
\hline & Port of Spain & 1968 & 15-34 & $28-40$ & (15) \\
\hline & Rural & 1968 & $15-34$ & $20-40$ & (15) \\
\hline \multirow[t]{3}{*}{ United States } & Eleven cities & 1962 & $17-35$ & 82 & (28) \\
\hline & Ten cities & 1966 & Pregnant women & 91 & (29) \\
\hline & Hawaii & 1963 & Pregnant women & 42 & (30) \\
\hline \multirow[t]{2}{*}{ Uruguay } & Montevideo & 1968 & 15-34 & $74-93$ & (15) \\
\hline & Rural & 1968 & $15-34$ & $82-90$ & (15) \\
\hline
\end{tabular}

rubella vaccine, beginning immediately after its introduction in 1969. In the United States the strategy adopted was to vaccinate all prepubertal children soon after the rubella vaccine was introduced, with routine vaccination of children at 12-15 months of age thereafter [usually as a combined measles-mumps-rubella (MMR) vaccine] (31). In part as a result of laws mandating that children receive the rubella vaccine before they start school, vaccine coverage in schoolaged children has been $\geq 95 \%$ since 1981. Additionally, vaccination of susceptible women of childbearing age was recommended, although it has not been carried out very aggressively. In Canada, different provinces initially adopted different approaches; some used the same strategy as the United States, and others adopted the strategy that was then pursued in the United Kingdom-vaccination of susceptible girls at 12-14 years of age.

Costa Rica began using the MMR vaccine in 1972, but there was no systematic nationwide use of rubella vaccine in other countries of the Americas until the 1980s. In 1982, Cuba began vaccinating 13 - to 15 -year-old schoolgirls, adding mass vaccination of all 
women up to 30 years old in early 1986 and mass vaccination of all children 1-14 years old (with MMR) in late 1986 and early 1987. Since 1987, MMR vaccine has been administered to all children at 1 year of age. Rubella has been eliminated from Cuba-no cases have occurred in more than 2 years (32).

Other countries in the Caribbean (particularly the English-speaking countries) began using rubella vaccine in the 1980s. Twelve Caribbean countries used MMR vaccine in their 1991 "catch-up" measles campaigns, reaching all children 1-14 years of age, and 10 countries used MMR in the 1996 measles "follow-up" campaigns. Currently, 22 countries in the Americas use rubella vaccine in their national immunization programs. ${ }^{3}$ All of them administer vaccine to children of both sexes at 12-15 months of age; in nine countries a second dose is administered at a later age. According to a recently published article, 78 countries worldwide have a national policy of using rubella vaccine (33).

\section{Cost-effectiveness of rubella vaccine}

Use of rubella vaccine has been shown to be highly cost-effective in the United States. A recent study found the overall benefit-to-cost ratio for use of MMR vaccine to be 21.3:1 if both direct and indirect costs are included. Considering only the individual rubella component, the ratio was 11.1:1 (34). In the English-speaking Caribbean, it was estimated that expenditures for the care and rehabilitation of the 1500 CRS cases that would be expected to occur over the next 15 years (in the absence of vaccination) would be approximately US\$ 60 million, whereas implementation of a strategy to eliminate CRS would cost less than US\$ 5 million (annual meeting of the

\footnotetext{
3 Anguilla, Antigua and Barbuda, Barbados, Bermuda, Canada, Cayman Islands, Chile, Costa Rica, Cuba, Dominica, Grenada, Jamaica, Montserrat, Panama, St. Kitts and Nevis, St. Lucia, St. Vincent, Trinidad and Tobago, Turks and Caicos Islands, United States of America, Uruguay, British Virgin Islands.
}

Expanded Program on Immunization Managers of the English-speaking Caribbean, Miami, FL, November 1996).

\section{OPTIONS FOR RUBELLA VACCINATION IN THE AMERICAS}

A hemispheric goal of measles elimination by the year 2000 has been established, and countries are making considerable progress toward this goal (35). Given the ease of adding measlesrubella (MR) or MMR vaccine to existing programs, questions have arisen about appropriate approaches to control or eliminate rubella. Currently there is no hemispheric policy on rubella immunization, nor has a goal for control or elimination been established. Consequently, it is most appropriate to consider options at this time.

The primary purpose of immunization against rubella is to prevent congenital rubella infection and its consequences, including CRS. Initially two different strategies were employed. The first sought to provide individual protection by vaccinating susceptible adolescent girls and women of childbearing age; it did not have a real effect on the overall transmission patterns of rubella. This approach was initially adopted in the United Kingdom. The second approach sought to interrupt transmission of rubella virus among children (the primary transmission groups), thus reducing the likelihood that a susceptible pregnant woman would be exposed. This approach was adopted in the United States and involved mass vaccination of all children less than 12 years of age followed by universal vaccination of children 12-15 months old. This strategy assumed that vaccine-induced immunity would be lifelong. As implemented, each of these strategies had some effect but neither was fully successful-in the United Kingdom, outbreaks of rubella and CRS continued among women who were older than the age for vaccination or who were missed by the program; in the United States, outbreaks of rubella were prevented but, because of in- sufficient vaccination of susceptible women of childbearing age, endemic levels of rubella and CRS persisted among young adults (31). If rubella vaccine is used only in young children, there will be an increase in the average age at infection, which, paradoxically, might increase the risk of a susceptible pregnant woman acquiring rubella infection and giving birth to a child with CRS (such an increase in CRS has not been documented). Infant/child immunization alone should not be considered an appropriate strategy for prevention of CRS.

Consequently, it has become clear that the first priority of any rubella control program should be to vaccinate susceptible women of childbearing age. This approach could be undertaken on an individual basis if resources did not permit a populationwide approach. However, even if undertaken populationwide, such an approach would not interrupt transmission of rubella, and women who were missed by the program would continue to be at risk. A complete rubella control and elimination program would incorporate individual protection of all women of childbearing age as well as vaccination of all children (of both sexes) to interrupt transmission of rubella.

Considering all these factors in the context of the Americas, the following recommendations seem appropriate:

- It is premature to establish a hemispheric goal of rubella elimination, but this could well be a logical development as progress continues with elimination of measles.

- Surveillance of CRS (and rubella) should be initiated throughout the Americas and should begin before, or at the same time as, implementation of a rubella vaccination program.

- Sufficient data exist to demonstrate the potential for occurrence of CRS in all countries of the Region, although the magnitude of the problem varies from country to country. Consequently, each country in the Region should establish a policy on rubella vaccination. 
- All countries should incorporate rubella vaccine (as MR or MMR) into childhood vaccination programs, both as part of routine childhood immunization at 12-15 months and as part of the followup measles campaigns reaching all children 1-4 years of age every 4 years. This will provide immediate protection to the vaccinees and, over the course of several years, will prevent epidemic rubella among children. However, it will not have an immediate effect on transmission of rubella among adults or on the occurrence of CRS.

- All countries should undertake one of the following steps:

1. Countries wishing to prevent and control CRS promptly should carry out a one-time mass campaign to vaccinate all females 5 through 39 years of age with rubella-containing vaccine (rubella, MMR, or MR). ${ }^{4}$ Operationally, adult women could be vaccinated postpartum, premaritally, at workplaces, or in colleges.

2. Countries wishing to prevent and control both rubella and CRS promptly should carry out a onetime mass campaign to vaccinate males and females 5-39 years of age with rubella-containing vaccine.

3. Countries that cannot do either of the above should begin vaccinating women of childbearing age.

4 From a programmatic perspective, serological screening of adult women probably would not be feasible or cost-effective in most settings, and all women of childbearing age should be asked if they are pregnant or anticipate becoming pregnant in the next 3 months; those who answer "yes" should be excluded and those who answer "no" should be vaccinated.
- When a hemispheric rubella elimination goal is established, countries will need to fill in any of the steps that were not previously carried out. ${ }^{5}$ The rubella experience of these countries will provide useful information for the eventual elimination of rubella virus from the Americas.

Acknowledgments. We wish to acknowledge the valuable comments of D. A. Henderson, Raul Montesano, and Susan Reef during the preparation of this paper.

\footnotetext{
Since this paper was written the CARICOM Council for Human and Social Development has passed a resolution that "every effort should be made to eliminate rubella and prevent the occurrence of new cases of congenital rubella syndrome in the Caribbean community by the end of the year $2000 "$ " (36).
}

\section{REFERENCES}

1. Orenstein WA, Bart KJ, Hinman AR, Preblud SR, Greaves WL, Doster SW, et al. The opportunity and obligation to eliminate rubella from the United States. JAMA 1984;251: 1988-1994.

2. Immunization Practices Advisory Committee. Rubella prevention: Recommendations of the Immunization Practices Advisory Committee (ACIP). MMWR Morb Mortal Wkly Rep 1990; 39:1-18.

3. Cutts FT, Robertson SE, Diaz-Ortega JL, Samuel R. Control of rubella and congenital rubella syndrome (CRS) in developing countries, part 1: Burden of disease from CRS. Bull World Health Organ 1997;75:55-68.

4. Williams SG, Hashim A, Reef S, Lewis M, Otten M, Williams W. Estimating the burden of congenital rubella syndrome in the Caribbean. Annual Conference of the Epidemic Intelligence Service, Atlanta GA; 1997.

5. Schatzmayr HG. Aspects of rubella infection in Brazil. Rev Infect Dis 1985;7:S53-S55.

6. Massad E, Azevedo-Neto RS, Burattini MN, Zanetta DMT, Coutinho FAB, Yang HM, et al. Assessing the efficacy of a mixed vaccination strategy against rubella in São Paulo, Brazil. Int J Epidemiol 1995;24:842-850.

7. Aguilera Rodríguez A, Kourí Flores G, Borbonet F, Ruíz Sánchez R, Barcelona Hernández S. Aislamiento del virus de la rubéola en material obtenido por aborto terapéutico. Rev Cubana Obstet Ginecol 1978;4:1-6.

8. Baxter DN. Control of the congenital rubella syndrome in Jamaica. West Indian Med J 1986; 35:50-54.
9. Moriarty BJ. Childhood blindness in Jamaica. Br J Ophthalmol 1988;72:65-67.

10. Sánchez Tenorio E, Torres Velasco R. Rubéola y embarazo. Resultados perinatales. Ginecol Obstet Mex 1992;60:141-145.

11. Saad de Owens C, Tristan de Espino R. Rubella in Panama: Still a problem. Pediatr Infect Dis J 1989;8:110-115.

12. Ali Z, Hull B, Lewis M. Neonatal manifestation of congenital rubella following an outbreak in Trinidad. J Trop Pediatr 1986;32:79-82.

13. Salisbury DM, Savinykh AI. Rubella and congenital rubella syndrome in developing countries: Selection of control strategies. Geneva: WHO; 1991. (Document EPI/GAG/91/WP.15).

14. Rawls WE, Melnick JL, Bradstreet CMP, Bailey M, Ferris AA, Lehmann NI, et al. WHO collaborative study on the sero-epidemiology of rubella. Bull World Health Organ 1967;37: 79-88.

15. Dowdle WR, Ferreira W, de Salles Gomes LF, King D, Kourany M, Madalengoitia J, et al. WHO collaborative study on the seroepidemiology of rubella in Caribbean and Middle and South American populations in 1968. Bull World Health Organ 1970;42:419-422.

16. Evans A, Cox F, Nankervis G, Opton E, Shope $\mathrm{R}$, Wells AV, et al. A health and seroepidemiological survey of a community in Barbados. Int J Epidemiol 1974;3:167-175.

17. Cotillo ZLG. Anticorpos neutralizantes contra rubéola num grupo de gestantes de São Paulo. Rev Saude Publica 1968;2:29-43.

18. De Azevedo Neto RS, Silveira ASB, Nokes DJ, Yang HM, Passos SD, Cardoso MRA, et al. Rubella seroepidemiology in a nonimmunized population of São Paulo State, Brazil. Epidemiol Infect 1994;113:161-173.

19. Villarejos VM, Arguedas Gamboa JA, Vargas Noar O, Cortés Vargas MA. Estudio de efectividad y seguridad de la vacuna contra la rubéola. Bol Oficina Sanit Panam 1971;70: 174-180.

20. Fuentes LG. Inmunidad a la rubéola en estudiantes admitidos en 1973 a la Universidad de Costa Rica. Acta Med Costarric 1973;16: 253-260.

21. Ramírez JA, León E, Torres E, Carrillo W, Sandi V. Seroepidemiología de la rubéola en mujeres costarricenses de edad fértil. Rev Costarric Cienc Med 1985;6:1-6.

22. Ramírez JA, Rosero-Bixby L, Oberle MW. Susceptibilidad al tétanos y rubéola en las mujeres de Costa Rica, 1984-85. Rev Costarric Cienc Med 1987;8:251-259.

23. Raquel Ordóñez B. Frecuencia de la rubéola en México: investigación epidémiologica. Salud Publica Mex 1969;11:731-740.

24. Tapia-Conyer R, Sepúlveda J, Salvatierra B, Muñoz O, Bustamante-Calvillo E, Álvarez y Muñoz T, et al. Factores determinantes de la rubéola en población de 10 a 14 años de edad en México. Salud Publica Mex 1992 34:211-221.

25. Justines G, Oro G, Fábrega P, Mans RA, Wong N. Presencia de anticuerpos contra la rubéola en comunidades urbanas y rurales en Panamá y evaluación de los resultados de pruebas de neutralización e inhibición de la hemoglutinación. Rev Med Panama 1981;6:176-182. 
26. Banffer JRJ. Sero-immunity against rubella in Surinam women. Trop Geogr Med 1971;23: 365-368.

27. Pitts OM, Ravenel JM, Finklea JF. Rubella immunity in Trinidad. Am J Epidemiol 1969; 89:271-276.

28. Sever JL, Schiff GM, Huebner RJ. Frequency of rubella antibody among pregnant women and other human and animal populations. Obstet Gynecol 1964;23:153-159.

29. Sever JL, Fuccillo DA, Gilkeson MR, Ley A, Traub R. Changing susceptibility to rubella. Obstet Gynecol 1968;32:365-369.

30. Sever JL, Fabiyi A, McCallin PF, Chu PT, Weiss W, Gilkeson MR. Rubella antibody among pregnant women in Hawaii. Am J Obstet Gynecol 1965;92:1006-1008.
31. Hinman AR, Bart KJ, Orenstein WA, Preblud SR. Rational strategy for rubella vaccination. Lancet 1983;i:39-41.

32. Galindo MA, Santín M, Resik S, Ribas MA, Guzmán M, Mas Lago P, et al. La eliminación del sarampión de Cuba. Rev Panam Salud Pública/Pan Amer J Public Health. Forthcoming, 1998.

33. Robertson SE, Cutts FT, Samuel R, DiazOrtega JL. Control of rubella and congenital rubella syndrome (CRS) in developing countries, part 2: Vaccination against rubella. Bull World Health Organ 1997;75:69-80.

34. Hatziandreu EJ, Brown RE, Halpern MT. A cost benefit analysis of the measles-mumps-rubella $(M M R)$ vaccine: Final report. Arlington, VA: Battelle; 1994.
35. de Quadros CA, Olive JM, Hersh BS, Strassburg MA, Henderson DA, Brandlin-Bennett $D$, et al. Measles elimination in the Americas: Evolving strategies. JAMA 1996;275:224-229.

36. Pan American Health Organization. Caribbean Community establishes rubella elimination goal. EPI Newsletter 1998;20:5.

Manuscript received on 19 February 1998. Revised version accepted for publication on 15 June 1998

RESUMEN La rubéola es una enfermedad vírica que produce poca morbilidad y pocas complicaciones, a no ser que la contraiga una mujer embarazada. La infección con rubéola durante el primer trimestre del embarazo a menudo termina en muerte fetal o en deformidades congénitas graves (síndrome de anomalías congénitas por rubéola, o SCR). La rubéola sigue siendo endémica en muchos países de América Latina y el Caribe. Se estima que quizá 20000 niños o más nacen cada año con SCR en países latinoamericanos y caribeños. Si bien la adición de la vacuna contra la rubéola a los programas de inmunización infantil de rutina disminuirá la circulación del virus entre los niños pequeños, no tendrá un impacto inmediato sobre la transmisión de la rubéola entre los adultos o sobre la frecuencia de SCR. Una campaña única dirigida a toda la población de hombres y mujeres de 5 a 39 años de edad en que se aplique la vacuna triple contra el sarampión, la parotiditis y la rubéola, o la vacuna doble contra el sarampión y la rubéola seguida de la vacuna triple como parte de la inmunización rutinaria de niños pequeños servirá para controlar y prevenir de manera inmediata tanto la rubéola como el SCR. En abril de 1988, los Ministros de Salud de países del Caribe angloparlante establecieron la meta de eliminar la rubéola para fines del año 2000 mediante la aplicación de la estrategia de vacunación aquí descrita. La experiencia que han tenido estos países en sus actividades de eliminación de la rubéola será fuente de información provechosa para la eliminación futura del virus de la rubéola de todo el territorio americano. 